\title{
INFLUENCE OF THICK EXTRACT FROM MAITAKE MUSHROOMS ON SIGNS OF INFLAMMATORY PROCESS IN EXPERIMENTAL TOXIC HEPATITIS
}

\author{
*I.I. Herasymets, L.S. Fira, I.I. Medvid \\ I. HORBACHEVSKY TERNOPIL NATIONAL MEDICAL UNIVERSITY, TERNOPIL, UKRAINE
}

Background. The priority of the contemporary pharmaceutical industry is to create effective, safe and inexpensive drugs to ensure the highest quality of care and optimal use of available raw materials.

Objective. The aim of our study was to investigate anti-inflammatory properties of the Maitake mushrooms thick extract in the experiment on rats with paracetamol(acetaminophen)-induced hepatitis.

Methods. 60 white male rats, weighing 180-210 g, randomized into 10 groups of 6 animals in each, were used for the experiment. Paracetamol hepatitis was simulated by acetaminophen intragastric administering in a dose of $1250 \mathrm{mg} / \mathrm{kg} 1$ time per day (for 2 days) as a suspension in 2\% starch gel solution. Maitake mushrooms thick extract, which was administered intragastrically 2 hours before the administration of acetaminophen and daily after the lesion in a dose of $150 \mathrm{mg} / \mathrm{kg}$ of the animal's body weight, was used for the toxic lesion correction. "Silibor" was selected as the comparison drug, which was administered according to the same scheme as the investigated extract in a dose of $20 \mathrm{mg} / \mathrm{kg}$ of the animal's body weight. Euthanasia was conducted on the $3^{\text {rd }}, 7^{\text {th }}$ and $10^{\text {th }}$ day of the experiment with sodium barbamyl. Liver homogenate and animal serum were used for the studies. The development of inflammatory processes was studied by the content of pro-inflammatory and antiinflammatory cytokines, as well as C-reactive protein in the serum of rats with toxic hepatitis and after the application of Maitake mushroom extract and the comparison drug.

Results. It was found that the introduction of acetaminophen to animals for the acute hepatitis simulation is accompanied by changes in the cytokine profile, i.e. an increase in the level of IL-6 and a decrease in the level of IL-4 in the serum of rats. Inflammatory development is evidenced by the content of C-reactive protein increase in the blood of the affected animals. The application of Maitake mushroom extract facilitated bringing the studied indicators almost to the level of intact control.

Conclusions. Reduction of inflammation signs in rats with the simulated paracetamol hepatitis under the influence of Maitake mushrooms thick extract confirms its anti-inflammatory properties.

KEYWORDS: maitake mushrooms, paracetamol, acute hepatitis, inflammation.

\section{Introduction}

Due to the serious consequences of hepatitis, there is a need for its earliest diagnosis and appropriate pharmacotherapy. The search for effective hepatoprotectors, which can influence the initial stages of initiation and development of inflammatory processes in the liver without side effects, is an important task of contemporary medicine $[1,2]$

Maitake mushroom has properties for which the Japanese have valued it for centuries: the ability to lose weight, to reduce discomfort and problems associated with menopause in women, to gently eliminate the unpleasant sensations of premenstrual syndrome, to lower blood sugar level, to reduce the effects of inflammation, to increase immunity due to $B$

*Corresponding author: Iryna Herasymets, Associate Professor, I. Horbachevsky Ternopil National Medical University, Ternopil, 46002, Ukraine. E-mail: irunaherasymets@gmail.com polysaccharides, available in the composition of the fungus $[3,4,5,6,7,8,9]$.

The aim of our study was to investigate the anti-inflammatory properties of the Maitake mushrooms thick extract in the experiment on rats with acute hepatitis induced by paracetamol (acetaminophen).

\section{Methods}

The material for the experimental work was a thick extract of Maitake mushrooms (TEOMM), obtained by scientists from the Department of Chemistry of Natural Compounds of the National University of Pharmacy.

The experiments were performed on white outbred male rats, weighing 180-210 g, kept on the standard diet of the vivarium of I. Horbachevsky Ternopil National Medical University. All studies were conducted in compliance with the rules of bioethics in accordance with the 
“European Convention for the protection of vertebrate animals, which are used for experimental and other scientific purposes" [10].

Intoxication with acetaminophen, which was administered intragastrically in a dose of $1250 \mathrm{mg} / \mathrm{kg} 1$ time per day for 2 days as a suspension in $2 \%$ starch gel solution, was a model of toxic lesions in rats $[11,12]$. TEOMM was administered intragastrically 2 hours before administration of the toxic agent and daily after the lesion in a dose of $150 \mathrm{mg} / \mathrm{kg}$ of the animal's body weight, which, in our previous studies, was found to be conditionally therapeutic for this extract [5]. "Silibor" (the active basis is silymarin) was chosen as the comparison drug. It was administered according to the same scheme as the investigated extract in a dose of $20 \mathrm{mg} / \mathrm{kg}$ (in terms of silymarin) of the animal's body weight. The value of the dose of the comparison drug was chosen according to the instructions for its application and using the coefficients of species sensitivity by Rybolovlev Yu. R. and his method of converting the dose for humans to the dose for rats [12, 13]. The animals were randomized into 10 groups, 6 rats each: the $1^{\text {st }}$ group - the animals of intact control; the $2^{\text {nd }}, 3^{\text {rd }}$ and $4^{\text {th }}$ - the animals affected by acetaminophen on the $3^{\text {rd }}$, $7^{\text {th }}$ and $10^{\text {th }}$ days of the study, respectively; the $5^{\text {th }}, 6^{\text {th }}$ and $7^{\text {th }}$ groups - the rats, which were injected with an extract of Maitake mushrooms in a dose of $150 \mathrm{mg} / \mathrm{kg}$ of body weight on the $3^{\text {rd }}, 7^{\text {th }}$ and $10^{\text {th }}$ days of the experiment, respectively; the $8^{\text {th }}, 9^{\text {th }}$ and $10^{\text {th }}$ groups of animals that were intragastrally administered with the drug silibor on the $3^{\text {rd }}, 7^{\text {th }}$ and $10^{\text {th }}$ days of the study, respectively. The rats were removed from the experiment by euthanasia under sodium barbamyl anesthesia. Euthanasia was conducted on the $3^{\text {rd }}, 7^{\text {th }}$ and $10^{\text {th }}$ days of the experiment. The study was subjected to liver homogenate and animal serum. Blood was taken from the heart of the animals.

The concentration of pro-inflammatory and anti-inflammatory interleukins in the serum of rats was determined by enzyme-linked immunosorbent assay using commercial kits (GEHealthcare: Amersham, UK) [14]. The content of C-reactive protein (CRP) was determined by immunoturbidimetric method $[15,16]$.

The obtained data were statistically processed by the program STATISTICA 12 . The significance of intergroup differences was determined using the criterion of rank sums of the Wilcoxon and the Mann-Whitney tests. $p$ values lower than 0.05 were considered to be statistically significant $[17,18]$.

\section{Results}

C-reactive protein is a non-glycosylated protein with a pentameric structure, which belongs to $\beta$-globulins. Due to its affinity to phosphorylcholine, which is a component of the cell walls of some bacteria and unicellular fungi, CRP is able to bind the relevant microbial cells and opsonize them for phagocytosis or lysis with complement $[16,19]$. CRP acts as a pro-inflammatory "trigger" that stimulates monocytic synthesis of cytokines such as tumour necrosis factor-a, interleukin-1 and interleukin-6. Thus, CRP performs an immunoregulatory function: it stimulates protective reactions and activates immunity [14].

CRP is determined in almost all pathological processes and diseases regarding tissue damage. The increased levels of C-reactive protein are one of the earliest laboratory signs of inflammation or tissue damage. Increased protein production by the liver begins 6 hours after the onset of inflammation [20].

We found out that in rats with acute hepatitis induced by acetaminophen, the serum CRP increased in 1.9, 2.4 and 2.7 times on the $3^{\text {rd }}, 7^{\text {th }}$ and $10^{\text {th }}$ days of the study, respectively, according to the group of intact control. After correction with TEOMM there was a probable decrease in the content of CRP in the serum of rats in $1.2,1.5$ and 2.1 times on the $3^{\text {rd }}, 7^{\text {th }}$ and $10^{\text {th }}$ days of the experiment, respectively, in the animals of control pathology. When using silibor, the studied indicator probably $(p \leq 0.05)$ decreased in 1.4 and 1.9 times on the $7^{\text {th }}$ and $10^{\text {th }}$ days of the experiment, respectively, for the animals with toxic hepatitis (Tab. 1).

The obtained results are a confirmation of the inflammatory processes development in the body of rats with acute hepatitis, which is caused by the action of acetaminophen.

Cytokines, a group of hormone-like proteins, peptides and mediators of inflammation, play a significant role in the pathogenesis of development and course of inflammatory processes. Imbalance in the cytokine system can have a significant effect on the course of inflammatory reaction [21].

Hepatocytes are very sensitive to the action of cytokines, as they contain a number of specific receptors on their surface, through which the regulation of protein synthesis, proliferation, differentiation, specialized functioning and apoptosis of liver cells is carried out. Pro- 
Table 1. The content of C-reactive protein in the serum $(\mathrm{mg} / \mathrm{I})$ of the rats affected by acetaminophen, and after application of the Maitake mushrooms extract $(M \pm m ; n=60)$

\begin{tabular}{|l|c|c|c|}
\hline \multirow{2}{*}{ Groups of animals } & \multicolumn{3}{|c|}{ Indicators } \\
\cline { 2 - 4 } & 3rd day & 7th day & 10th day \\
\hline IC & $3.51 \pm 0.28$ & $3.51 \pm 0.28$ & $3.51 \pm 0.28$ \\
\hline CP & $6.83 \pm 0.23^{*}$ & $8.47 \pm 0.24 *$ & $9.54 \pm 0.32 *$ \\
\hline CP+silibor & $6.10 \pm 0.20$ & $5.93 \pm 0.29 * *$ & $5.08 \pm 0.23 * *$ \\
\hline CP+TEOMM & $5.71 \pm 0.18 * *$ & $5.63 \pm 0.28 * *$ & $4.49 \pm 0.3^{* *}$ \\
\hline
\end{tabular}

Notes. Here and in the following tables * - probable changes between the rate of the control and paracetamol-affected animals, ** - probable changes between the rates of the paracetamol-affected and treated animals.

inflammatory cytokines: IL-1, IL-6, IL-8, IL-12, TNF-, IFN-y are involved in the specific immune response triggering, while anti-inflammatory cytokines: IL-4, IL-10, IL-13, TGF are involved in the development of reactions of the anti-inflammatory process and inhibit the synthesis of pro-inflammatory interleukins $[14,15,20,21]$.

Our further research was to study the content of pro-inflammatory and anti-inflammatory cytokines, IL-4 and IL-6, in the blood serum of rats with simulated acetaminophen hepatitis, as well as to study the corrective effect of TEOMM and silibor on them.

Numerous studies confirm that violation of normal proportions of pro-inflammatory and anti-inflammatory cytokines synthesis can lead to disruption of regulation and development of vital immune reactions and, above all, inflammatory reactions. In the case of violations of local protective reactions, inflammation spreads, cytokine synthesis increases, then they enter the bloodstream and have their effect on the systemic level, i.e. have their effect on almost all organs and systems of the body [19, 20,22].

It was experimentally established that during the formation of acute hepatitis in rats on the $3^{\text {rd }}$ day of the study, the content of IL- 6 increased by $82 \%$ compare to the intact animals. On the $7^{\text {th }}$ and $10^{\text {th }}$ days of the experiment, the content of the studied indicator increased by $126 \%$ and $150 \%$, respectively, compare to the intact control animals (Tab. 2).

TEOMM application for correction the detected disorders in toxic hepatitis led to a probable decrease in the content of IL- 6 on the $7^{\text {th }}$ day of the study compare to control. The comparison drug Silibor had a positive effect on this indicator, although slightly inferior to our studied extract.

Local inflammatory process, after introduction of a pro-inflammatory agent, is important for healing and protection of the body from infection. However, excessive accumulation of pro-inflammatory cytokines in the blood leads to generalized sepsis and multiorgan failure. It is anti-inflammatory interleukins, which include IL-4 and IL-10, are able to reduce inflammation and cause a cessation of the inflammatory response [14, 15].

Hence, it was advisable to study the content of anti-inflammatory cytokines, in particular IL-4, in the serum of rats with toxic lesion.

After affection of animals with acetaminophen in the serum, the IL-4 content decrease in 1.4, 1.5 and 1.6 times was observed on the $3^{\text {rd }}, 7^{\text {th }}$ and $10^{\text {th }}$ days of the experiment, respectively, compare to the group of intact control animals (Tab. 3).

TEOMM caused a probable increase in the IL- 4 content by $30 \%$ and $46 \%$ on the $7^{\text {th }}$ and $10^{\text {th }}$ days of the study, respectively, in the animals with toxic hepatitis. When using the comparison drug, a probable $(p \leq 0.05)$ increase in the cytokine content on the $7^{\text {th }}$ day in 1.3 times and in 1.4 times on the $10^{\text {th }}$ day of the study compare to the control pathology group was noted.

The obtained results suggest that the use of TEOMM in rats at a dose of $150 \mathrm{mg} / \mathrm{kg}$ for 10

Table 2. The content of IL- 6 in the serum $(\mathrm{pg} / \mathrm{l})$ of the rats affected by paracetamol, and after application of the Maitake mushrooms extract $(M \pm m ; n=60)$

\begin{tabular}{|l|c|c|c|}
\hline \multirow{2}{*}{ Groups of animals } & \multicolumn{3}{|c|}{ Indicators } \\
\cline { 2 - 4 } & 3rd day & 7th day & 10th day \\
\hline IC & $2.96 \pm 0.22$ & $2.96 \pm 0.22$ & $2.96 \pm 0.22$ \\
\hline CP & $5.38 \pm 0.30 *$ & $6.69 \pm 0.34 *$ & $7.39 \pm 0.27 *$ \\
\hline CP+silibor & $4.93 \pm 0.21$ & $4.51 \pm 0.26 * \star$ & $4.35 \pm 0.29 * *$ \\
\hline CP+TEOMM & $4.85 \pm 0.16$ & $4.22 \pm 0.22 * *$ & $3.98 \pm 0.26 * *$ \\
\hline
\end{tabular}


Table 3. The content of IL-4 in the serum (pg/I) of the rats affected by paracetamol, and after application of the Maitake mushrooms extract $(M \pm m ; n=60)$

\begin{tabular}{|l|c|c|c|}
\hline \multirow{2}{*}{ Groups of animals } & \multicolumn{3}{|c|}{ Indicators } \\
\cline { 2 - 4 } & 3rd day & 7th day & 10 th day \\
\hline IC & $1.57 \pm 0.08$ & $1.57 \pm 0.08$ & $0.96 \pm 0.09$ \\
\hline CP & $1.14 \pm 0.05^{*}$ & $1.03 \pm 0.07 *$ & $1.34 \pm 0.06$ ** \\
\hline CP+silibor & $1.22 \pm 0.07$ & $1.29 \pm 0.08 * *$ & $1.40 \pm 0.08^{*}$ \\
\hline CP+TEOMM & $1.29 \pm 0.05$ & $1.34 \pm 0.06 * *$ & \\
\hline
\end{tabular}

days has a positive effect on the initial stages of the inflammatory reaction.

\section{Discussion}

The inflammatory process caused by immune mechanisms is significant in the pathogenesis of diseases. CRP is a marker of systemic inflammation. Therefore, the experimentally revealed increase in its level in the serum of animals with toxic lesion indicates an inflammatory process in the body. CRP is one of the activators of the complement system - a compound of complex proteins involved in the formation of the body's immune response [16].

Cytokines are a major factor in the interaction between immune cells and somatic cells. Determination of their concentration in the blood provides information about the functional activity of different types of immunocompetent cells, severity of the inflammatory process, its transition to the systemic level, prognosis of the disease. Excessive production of cytokines and other mediators of inflammation disrupts regulatory function of the immune system, their uncontrolled release takes place, as well as the imbalance between pro-inflammatory and antiinflammatory cytokines with a predominance of pro-inflammatory. As a result, the mediators of inflammation from the factors that protect the body become damaging for it [15].

The study of the content of the pro-inflammatory cytokine IL- 6 showed a probable increase throughout the experiment. At the same time, the serum content of the anti-inflammatory cytokine IL-4 decreased. This indicates an imbalance of pro-inflammatory and anti-inflammatory cytokines caused by toxic liver damage by acetaminophen.
We established an anti-inflammatory effect of the studied extract, which consists in changing the cytokine profile, in particular in reducing the dynamics of the pro-inflammatory IL- 6 content and increase in the anti-inflammatory cytokine IL-4 content compare to the group of intact control rats.

\section{Conclusions}

It was established that in cases of acute hepatitis in the rats induced by acetaminophen, the concentration of CRP increased in the blood serum, the content of pro-inflammatory IL- 6 probably increased and the content of antiinflammatory cytokine IL-4 decreased, which indicated the development of inflammatory processes in the affected animals.

The application of a Maitake mushrooms thick extract had a positive effect on the content of C-reactive protein and cytokines in the serum of the animals with acute hepatitis, which indicated its anti-inflammatory properties and the relevance of further study to creation of effective drugs.

\section{Funding}

This research received no external funding.

\section{Conflict of interest}

The authors declare no conflict of interests in this study.

\section{Author Contributions}

Herasymets I.I. - conceptualization, data curation, formal analysis, investigation, visualization, article writing; Fira L.S. - conceptualization, supervision, validation, methodology; Medvid I.I. - formal analysis, investigation, software. 


\title{
ВПЛИВ ГУСТОГО ЕКСТРАКТУ 3 ГРИБІВ МАЙТАКЕ НА ОЗНАКИ ЗАПАЛЬНОГО ПРОЦЕСУ ЗА ЕКСПЕРИМЕНТАЛЬНОГО ТОКСИЧНОГО ГЕПАТИТУ
}

\author{
I.I. Герасимець, Л.С. Фіра, I.I. Медвідь \\ ТЕРНОПІЛЬСЬКИЙ НАЦІОНАЛЬНИЙ МЕДИЧНИЙ УНІВЕРСИТЕТ IМЕНІ І.Я. ГОРБАЧЕВСЬКОГО, \\ ТЕРНОПІЛЬ, УКРАЇНА
}

Вступ. Пріоритетним завданням сучасної фармацевтичної галузі є створення ефективних, безпечних та доступних лікарських засобів, щоб забезпечити максимально високу якість надання медичної допомоги та оптимального використання наявних сировинних ресурсів.

Мета роботи. Метою нашого дослідення було вивчити протизапальні властивості густого екстракту з грибів майтаке в експерименті на щурах із гепатитом, індукованим парацетамолом (ацетамінофеном).

Методи. Для проведення експерименту було використано 60 білих шурів-самців, масою 180-210 г, рандомізованих на 10 груп по 6 тварин у кожній. Парацетамоловий гепатит моделювали шляхом введення ацетамінофену інтрагастрально у дозі 1250 мг/кг 1 раз на добуу вигляді суспензії в 2 \% розчині крохмального гелю протягом 2 діб. Для корекції токсичного ураження використовували густий екстракт грибів майтаке, який вводили інтрагастрально за 2 години до введення ацетамінофену та щоденно після ураження в дозі 150 мг/кг маси тіла тварини. Як препарат порівняння обрали “Силібор" (виробник - ТОВ «Фармацевтична компанія «Здоров'я»), який вводили за тією ж схемою, що і екстракт майтаке в дозі 20 мг/кг маси тіла тварини. На 3-тю, 7-му та 10-ту добу експерименту здійснювали евтаназію щурів із використанням барбамілу натрію. Для досліджень брали гомогенат печінки та сироватку крові. Розвиток запальних процесів вивчали за вмістом про- та протизапальних цитокінів, а також С-реактивного протеїну у сироватці крові щурів із токсичним гепатитом та після застосування екстракту грибів майтаке та препарату порівняння.

Результати. Встановлено, що введення тваринам ацетамінофену для моделювання гострого гепатиту супроводжується змінами цитокінового профілю, а саме, зростанням рівня IL-6 ma зменшенням рівня IL-4 у сироватці крові щурів. Про розвиток запального процесу свідчить підвищення вмісту С-реактивного протеїну в крові уражених тварин.Застосування екстракту грибів майтаке сприяло наближенню досліджваних показників до рівня інтактного контролю.

Висновки. Зменшення ознак запального процесу у щурів при модельованому парацетамоловому гепатиті під впливом густого екстракту грибів майтаке підтверджує його протизапальні властивості.

КЛючОВІ СлОВА: гриби майтаке, парацетамол, гострий гепатит, запалення.

\section{Information about the authors}

Herasymets I.I. - PhD in Pharmacy, Associate Professor, Department of Pharmacology and Clinical Pharmacology, I. Horbachevsky Ternopil National Medical University.

ORCID0000-0001-7108-3251, e-mail: irunaherasymets@gmail.com

Fira L.S. - Doctor of Biological Sciences, Professor, Head of the Department of Pharmacy of the Institute of Postgraduate Education, I. Horbachevsky Ternopil National Medical University.

ORCID 0000-0002-5325-0973, e-mail: ludafira@ukr.net

Medvid I.I. - PhD in Medicine, Assistant Professor, Department of Microbiology, Virology and Immunology, I. Horbachevsky Ternopil National Medical University.

ORCID 0000-0003-4703-4438, e-mail: medvid_ii@meta.ua

\section{References}

1. Beger RD, Bhattacharyya S, Yang $X$, et al. Translational biomarkers of acetaminophen-induced acute liver injury. Arch Toxicol. 2015;89(9):1497-522.

2. Caparrotta TM, Antoine DJ, Dear JW.: Are some people at increased risk of paracetamol-induced liver injury? A critical review of the literature. Eur J Clin Pharmacol. 2017;74(2):147-160.

3. Xiao C, Wu Q, Xie Y, et al. Hypoglycemic effects of Grifola frondosa (Maitake) polysaccharides F2 and F3 through improvement insulin resistance in diabetic rats. Food and Function. 2015; Issue 11: 29.
4. Ji H-Y, Yu J, Liu A. Structural characterization of a low molecular weight polysaccharide from Grifola frondosa and its antitumor activity in $\mathrm{H} 22$ tumor-bearing mice. Journal of Functional Foods. 2019;V.61:10342.

DOI: 10.1016/j.jff.2019.103472

5. Herasymets II, Fira LS, Medvid II. Study of the conditionally therapeutic dose of thick extract from Maitake mushrooms. Colloquium-journal. 2020; 13(65):5-9.

DOI: $10.24411 / 2520-6990-2020-11853$. 
6. Li Q, Zhang F, Chen G, et al. Purification, characterization and immunomodulatory activity of a novel polysaccharide from Grifola frondosa. Int J Biol Macromol. 2018;V.111:1293-1303.

7. Xiang Q, Zhang W, Li Q, et al. Investigation of the uptake and transport of polysaccharide from Se-enriched Grifola frondosa in Caco-2 cells model. Int J Biol Macromol. 2020;V.158:1330-1341.

8. Ma X, Zhou F, Chen Y, et al. A polysaccharide from Grifola frondosa relieves insulin resistance of HepG2 cell by Akt-GSK-3 pathway. Glycoconjugate Journal. 2014;31:335-363.

9. Zhang Y, Sun D, Meng Q, et al. Grifola frondosa polysaccharides induce breast cancer cell apoptosis via the mitochondrial-dependent apoptotic pathway. International journal of molecular medicine. 2017; 40(4):1089-1095.

10. Gross D, Tolba R. Ethics in Animal-Based Research. Eur Surg Res. 2015;55(1-2):43-57.

11. Stefanov AV.: Preclinical trials of medicines. Guidelines: under. ed. Corresponding Member AMS of Ukraine AV Stefanov. K: Avitsenna. 2002;568.

12. Vashkeba-Bitler EM. Determination of antiinflammatory and antimicrobial activity of the extract from the aerial part of horseradish. Pharmaceutical Review. 2014;4:122-124.

13. Rybolovlev YR, Rybolovlev RS. Dosing of substances for mammals according to the constants of biological activity. Reports of the USSR Academy of Sciences. 1979;T.247,6:1513-1516.

14. Zhou B, Shu B, Yang J, et al. C-reactive protein, interleukin- 6 and the risk of colorectal cancer: a meta-analysis. Cancer Causes Control. 2014; 25(10): 1397-1405.

15. Altynbaeva YI, Teplova SN. Cell damage markers, cytokines and terminal stable metabolites of nitric oxide in saliva in smoking patients in the early stages of chronic obstructive pulmonary disease. Cytokines and inflammation, 2011;4:15-22.

16. Alybaeva KM, Berdyyarova NA, Mukhamedzhanova NK, et al. Analysis of the quantitative determination of the level of C-reactive protein and procalcitonin in patients with infectious diseases. Bulletin of AGIUV. 2015;1-2:36-40.

17. Jannot AS, Agoritsas T, Gayet-Ageron A, et al. Citation bias favoring statistically significant studies was present in medical research. J Clin Epidemiol. 2013; 66(3): 296-301.

DOI: 10.1016/j.jclinepi.2012.09.015.

18. Shelamova MA, Insarova NI, Lieshchienko VH. Statistical analysis of medical and biological data using the EXCEL program. Minsk, BGMU. 2010; 96.

19. Zhang $X$, Liu S, Zhou Y.: Circulating levels of C-reactive protein, interleukin- 6 and tumor necrosis factor-a and risk of colorectal adenomas: a metaanalysis. Oncotarget. 2016; 27, 7(39): 64371-64379.

20. Heikkilä K, Harris R, Lowe G, et al.: Associations of circulating C-reactive protein and interleukin-6 with cancer risk: findings from two prospective cohorts and a meta-analysis. Cancer Causes Control. 2009;20:15-26.

DOI: $10.1007 / s 10552-008-9212-z$.

21. Nam J, Park K, Park E, et al.: Interleukin-13/4-induced oxidative stress contributes to death of hippocampal neurons in aß1-42-treated hippocampus in vivo. Antioxid Redox Signal. 2012;16(12):1369-83.

DOI: 10.1089/ars.2011.4175.

22. Gaber W, Azkalany GS, Gheita TA.: Clinical significance of serum interleukin- 6 and -174 G/C promoter polymorphism in Rheumatoid arthritis patients. Egypt Rheumatol. 2013;35(2):107-113.

Received 17 May 2021; revised 28 May 2021; accepted 3 Jun 2021.

This is open access article distributed under the Creative Commons Attribution License, which permits unrestricted use, distribution, and reproduction in any medium, provided the original work is properly cited. 